\title{
Adipokine inflammation and insulin resistance: the role of glucose, lipids and endotoxin
}

\author{
M K Piya ${ }^{1,2}$, P G McTernan ${ }^{1}$ and S Kumar ${ }^{1,2}$ \\ ${ }^{1}$ Division of Metabolic and Vascular Health, Clinical Sciences Research Laboratories, Warwick Medical School, \\ University Hospital Site, University of Warwick, Coventry CV2 2DX, UK \\ ${ }^{2}$ Warwickshire Institute for the Study of Diabetes, Endocrinology and Metabolism, University Hospitals Coventry \\ and Warwickshire NHS Trust, Walsgrave, Coventry CV2 2DX, UK
}

Correspondence should be addressed to M K Piya Email

m.k.piya@warwick.ac.uk

\begin{abstract}
Adipose tissue is an active endocrine organ, and our knowledge of this secretory tissue, in recent years, has led us to completely rethink how our body functions and becomes dysregulated with weight gain. Human adipose tissue appears to act as a multifunctional secretory organ with the capacity to control energy homoeostasis through peripheral and central regulation of energy homoeostasis. It also plays an important role in innate immunity. However, the capability to more than double its original mass to cope with positive energy balance in obesity leads to many pathogenic changes. These changes arise within the adipose tissue as well as inducing secondary detrimental effects on other organs like muscle and liver, including chronic low-grade inflammation mediated by adipocytokines (adipokine inflammation). This inflammation is modulated by dietary factors and nutrients including glucose and lipids, as well as gut bacteria in the form of endotoxin or LPS. The aim of this current review is to consider the impact of nutrients such as glucose and lipids on inflammatory pathways, specifically within adipose tissue. Furthermore, how nutrients such as these can influence adipokine inflammation and consequently insulin resistance directly through their effects on secretion of adipocytokines (TNF $\alpha$, IL6 and resistin) as well as indirectly through increases in endotoxin is discussed.
\end{abstract}
Key Words
- Adipokine
- Insulin resistance
- Inflammation
- Lipotoxicity
- Endotoxin

\section{Evolution and inflammation}

Chronic low-grade inflammation is thought to be key in the pathogenesis of insulin resistance, type 2 diabetes mellitus (T2DM) and cardiovascular disease (CVD) that is associated with obesity-mediated diabetes (Hotamisligil 2006, Ouchi et al. 2011). The role of adipose tissue as an endocrine organ, secreting numerous hormones and proinflammatory cytokines (adipokines), seems to be central to subclinical inflammation in adipose tissue. And while obesity exacerbates this process, the mediators and underlying mechanisms for this appears to be a complex multifactorial phenomenon (Hotamisligil 2006, Nishimura et al. 2009, Ouchi et al. 2011).

It is clear that during weight gain, our normal physiological response to inflammatory insults misalign but our understanding as to why this occurs is incomplete. It is clear that immunity has an important protective role within the human body, and an inflammatory response coordinates more efficient wound healing as well as response to infections. From an evolutionary perspective, 
the immune function is heavily preserved across species with Drosophila melanogaster (commonly known as the fruit fly) providing valuable insight into immune function. Approximately $75 \%$ of human disease-related genes have a recognisable match in the genome of Drosophila (Reiter et al. 2001), and Drosophila have been used as a genetic model for several human disease mechanisms underlying aging, oxidative stress, immunity, T2DM and heart disease (Tanji \& Ip 2005, Kühnlein 2010, Diop \& Bodmer 2012). The D. melanogaster immune system can be divided into two innate immune responses: humoral and cell mediated. The former is a systemic response mediated through the Toll and immune deficiency (Imd) pathways, which are parallel systems for detecting microbes. The Toll and Imd pathways are homologous to the mammalian Toll-like receptor (TLR) and tumour necrosis factor receptor (TNFR) signalling pathways respectively and are essential for Drosophila to survive infection. Spatzle, a known ligand for the Toll pathway in flies, is produced in response to Gram-positive bacteria, parasites and fungal infection. Upon infection, pro-Spatzle is cleaved by protease Spatzle processing enzyme (SPE) to become active Spatzle, which then binds to the Toll receptor located on the cell surface of the fat body and the haemocytes and dimerises for activation of downstream nuclear factorkappa B (NF-кB) signalling pathways (a key factor that regulates the transcription of numerous pro-inflammatory cytokines/adipokines). Although the pathway of innate immune activation via TLRs is different in mammalian physiology, it leads to the same activation of the NF- $\mathrm{KB}$ signalling pathways (Tanji \& Ip 2005, O'Neill et al. 2009). Of note, the Drosophila fat body performs the function of the mammalian liver, haematopoietic, immune system and adipose tissue as one whole unit; in mammals, each of these tissues have become highly specialised, yet their functions often overlap, particularly in the case of immunity, which in both the Drosophila and the mammal are vital to survival (Hotamisligil 2006). Therefore, the need to conserve the immune functions across species and evolution appears paramount. Specifically, in the case of human adipose tissue, this tissue is an active site of innate immune response, through activation of TLRs and downstream NF- $\kappa \mathrm{B}$ signalling, with the pre-adipocytes preserving phagocytic type qualities and responding to inflammatory insults. In addition, adipose tissue also contains a large number of macrophages and thus may support the function as a first line of defence against superficial wounds or stimuli. As adipose tissue may lie directly underneath the basal epidermal membrane, across the human body, this would allow a quick inflammatory response to wound damage and limit infection effectively. From an evolutionary perspective, in mammals, the subcutaneous locality of adipose tissue to promote local wound healing would seem an advantage. However, obesity alters normal physiology and development of abdominal adipose tissue appears to exacerbate the inflammatory response, and the underlying cause for this has been the subject of considerable research.

\section{Adipose tissue: a site of inflammation}

From previous studies, it is well established that when there is an expansion of adipose tissue, such as that observed in obesity, there is a sustained inflammatory response accompanied by adipokine dysregulation, which leads to chronic subclinical inflammation as well as insulin resistance (Shoelson et al. 2006). Although BMI as a measure of obesity is a good predictor of all-cause and cardiovascular mortality, as recently described in two separate meta-analyses (ProspectiveStudiesCollaboration 2009, Berrington de Gonzalez et al. 2010), overall mortality and especially cardiovascular mortality seems to be better predicted by abdominal or central obesity in addition to BMI (Koster et al. 2008, Pischon et al. 2008, Czernichow et al. 2011). This highlights the importance of the site of deposition of adipose tissue and how the locality of the adipose tissue affects such function, as all fat depots are not equal in terms of their function and pathogenic nature. There are several sites of subcutaneous white adipose tissue, including the abdomen, thigh, mammary region, gluteofemoral adipose tissue as well as epidermal, while visceral abdominal depots comprise omentum, mesenteric and peri-renal adipose tissue. Adipose tissue also lies on the heart (epicardial adipose tissue) (Baker et al. 2009) and brown or beige/brite adipose tissue has recently been described in adult humans that, unlike white adipose tissue, provides the release of energy via non-shivering thermogenesis (Cypess et al. 2009, van Marken Lichtenbelt et al. 2009, Wu et al. 2012a).

Many previous studies have also described visceral adipose tissue activity as a key determinant of metabolic risk (Peiris et al. 1989, Després et al. 1990, 2000, Couillard et al. 1996, Wajchenberg 2000, Smith et al. 2001). However, many of these initial studies were examining triglyceride turnover in visceral fat as the marker of metabolic risk, and this may not be relevant for adipokine release or take into account the size of abdominal subcutaneous fat and the pathogenic nature of this tissue (Fisher et al. 2002, Harte et al. 2003a,b, McTernan et al. 2003, Kos et al. 2007, 2009, Jernås et al. 2009,

Published by Bioscientifica Ltd. 
Saiki et al. 2009, Carobbio et al. 2011, McGee et al. 2011). While gluteofemoral subcutaneous fat is considered to have a protective effect and reduce metabolic risk - with the classic pear-shaped obesity and lower waist:hip ratio (Manolopoulos et al. 2010) - abdominal subcutaneous adipose tissue appears to be more active than previously thought, secreting a multitude of pro-inflammatory adipocytokines (Fisher et al. 2002, Harte et al. 2003a,b, McTernan et al. 2003, Kos et al. 2007, 2009, Jernås et al. 2009, Saiki et al. 2009, McGee et al. 2011, Youssef-Elabd et al. 2012). There is expansion of the adipose tissue depots in obesity with both hyperplasia and hypertrophy, coupled with increased macrophage infiltration and, consequently, inflammation. Although obesity can lead to an expansion of the visceral depot to as much as $20 \%$ total fat mass, subcutaneous adipose tissue accounts for the remaining $80 \%$ and also responds to inflammatory insults (Mlinar \& Marc 2011). Furthermore, while adipose tissue from lean individuals may preferentially secrete anti-inflammatory adipokines such as adiponectin, transforming growth factor $\beta$ (TGF $\beta$ ), interleukin 10 (IL10), IL4, IL13, ILRa and apelin, in obesity pro-inflammatory adipocytokines such as TNF $\alpha$, IL6, leptin, visfatin, resistin, angiotensin II and plasminogen activator inhibitor 1 are released, as well as several interleukins (Ouchi et al. 2011) coupled with a reduction in secretion of anti-inflammatory adipokines (Table 1).

It would also appear that adipokines have different functions in normal-weight individuals and in the obese. In lean individuals, adipokines mediate physiological functions while in states of metabolic disease the adipokines have altered effects, modulating insulin resistance either directly by affecting the insulin signalling pathway or indirectly via stimulation of inflammatory pathways. Serine phosphorylation of insulin receptor substrate (IRS) 1 by various adipokines directly or via inflammatory pathways including the c-Jun N-terminal kinases (JNK) pathway and I-Kappa B kinase $\beta$ (IKK $\beta$ )/ NF- $\kappa B$ pathway disrupts the insulin signalling pathways, possibly giving rise to insulin resistance (Pirola et al. 2004, Tilg \& Moschen 2008, Kalupahana et al. 2012).

\section{Mediators of adipokine release and systemic inflammation}

The importance of adipocytes and recruitment of macrophages into adipose tissue and their impact on innate immunity and the inflammation response are now widely recognised, even though there is controversy over the precise sequence of events in the pathogenesis and also the role of the different cells involved. There is also now a much improved understanding of the impact of glucotoxicity and lipotoxicity as key factors leading to the pathogenesis of obesity-mediated diabetes that is likely to be a consequence of subclinical inflammation in adipose tissue. Approaches to a reductionist explanation of the pathogenesis of 'diabesity' overlooks the sheer complexity of the disorder - the potential crosstalk of insults, such as glucose and lipids and their impact on inflammatory pathways. These next sections will elaborate on the impact of glucose, lipids and gut-derived bacteria - endotoxin - and their effects on inflammatory pathways, as this review evaluates the triple insult of these factors on T2DM pathology. Figure 1 gives an overview of the effect of glucose, lipids and endotoxin on adipokine inflammation and insulin resistance.

\section{The effect of glucose on adipokine inflammation}

The presence of T2DM or impaired glucose tolerant (IGT) confers a state of chronic low-grade inflammation as well as higher cardiovascular risk. A raised HbA1c, a measure of hyperglycaemia, has been linked with increased cardiovascular mortality and morbidity in various studies (Stratton et al. 2000, Selvin et al. 2004, Gerstein et al. 2005). Hyperglycaemia occurs in tandem with hyperinsulinaemia, although in T2DM subjects given low levels of exogenous insulin to produce normoglycaemia there was a reduction in TLR expression in mononuclear cells (Ghanim et al. 2008). However, hyperinsulinaemia has been associated with increased inflammation, for example in patients with T2DM. In healthy individuals, hyperinsulinaemic euglycaemic clamps resulted in a significantly increased IL6 response when endotoxin was infused (Soop et al. 2002). Furthermore, insulin is known to increase lipogenesis and increase triglyceride synthesis, further fuelling free fatty acid-mediated inflammation. Free fatty acids are also implicated in inflammation and insulin resistance, as described later in this review. While hyperglycaemia can induce oxidative stress (Dandona et al. 2007), studies have shown that acute hyperglycaemia can increase pro-inflammatory adipokines such as IL6 and TNF $\alpha$ levels in non-diabetic as well as IGT subjects (Esposito et al. 2002) and IL6 in non-diabetic and T2DM subjects (Ruge et al. 2009).

The activation of these pro-inflammatory factors has been investigated in vitro, with hyperglycaemic-type conditions shown to activate the innate immune pathway in abdominal subcutaneous adipose tissue as well as isolated abdominal subcutaneous adipocytes, as denoted

Published by Bioscientifica Ltd. 
Table 1 List of adipokines. Adapted and updated from Frühbeck et al. (2001) and Kusminski et al. (2007)

\begin{tabular}{lll} 
Adipokine & Function/effect \\
\cline { 1 - 2 } Leptin & $\begin{array}{l}\text { Satiety signal. Promotes } \\
\text { increased energy } \\
\text { expenditure }\end{array}$
\end{tabular}

Adiponectin Improves energy homoeostasis, insulin sensitivity and glucose uptake. Anti-inflammatory properties

TNF $\alpha$

PAl-1 Potent inhibitor of

Reduces insulin secretion and insulin sensitivity. Stimulates lipolysis

Affects glucose and lipid metabolism. Improves insulin sensitivity and glucose tolerance

\section{Distribution}

Secreted predominantly by WAT, Sc AT > Om AT. Also derives from BAT, skeletal muscle, stomach and plasma

Secreted exclusively by adipocytes. mRNA and protein in SC AT > Om AT. 2-3x greater secretion in females

Predominantly expressed by macrophages. Also expressed by WAT adipo$35 \%$ of the basal supply is derived from WAT. Produced by macrophages, fibroblasts, endothelial cells and skeletal muscle cells

Affects glucose metabolism and causes insulin resistance in rodents. In humans, it acts more as a pro-inflammatory cytokine fibrinolytic pathway

IL8

Neutrophil chemotaxis and degranulation. Pro-atherogenic RBP4 Implicated in insulin resistance as well as increased hepatic glucose output and impaired muscle insulin signalling

TGF $\beta \quad$ Varied role in proliferation differentiation, apoptosis and development

MCP1 Increases insulin resistance, macrophage infiltration in adipose tissue and hepatic steatosis

RANTES Pro-inflammatory

Visfatin/PBEF/ Pro-inflammatory and NAMPT insulin mimicking

Chemerin Affects adipogenesis, inflammation as well as glucose metabolism

Vaspin Improves insulin sensitivity

Nesfatin

Acts centrally to reduce appetite

Omentin Increases insulin sensitivity

Multifunctional, produced by variety of cells. Inhibitor of differentiation

Secreted by WAT

Secreted by T cells, monocytes and to a lesser degree in WAT

Secreted by adipocytes

Secreted by WAT

Also secreted in skin hypothalamus, pancreatic islets and stomach

Secreted in brain tissue, $\beta$ cells and adipose tissue cytes, Sc AT> Om AT

In rodents, secreted by
WAT. In humans, secreted in human obesity, macrophages and WAT T2DM and CVD

Expressed by Sc and Om AT. $\uparrow$ In human obesity Positive correlation with abdominal adiposity Predominantly macrophages and monocytes. Adipocytes: Om $>$ Sc Secreted by adipocytes, macrophages and liver metabolic syndrome and T2DM

$\uparrow$ In obesity, positively correlates with BM and TNF $\alpha$

$\uparrow$ In obesity and insulin resistance

\section{Evidence}

Meier \& Gressner (2004)

and Mantzoros et al. (2011)

$\downarrow$ after fasting or

$\downarrow$ In mouse models of obesity and insulin $\mathrm{db} / \mathrm{db}$ ) $\downarrow$ In human

After weight loss human obesity: obese (2X) $>$ lean. $\downarrow$ Adipose

morbidly obese patients. $\downarrow$ After weight loss

Fisher et al. (2002), Spranger et al. (2003) and Whitehead et al. (2006)

Hotamisligil et al. (1993) Hube \& Hauner (1999) and Tzanavari et al. (2010)

Fried et al. (1998), Bastard et al. (2000) and Eder et al. (2009)

McTernan et al. (2002a 2006) and Schwartz \& Lazar (2011)

Shimomura et al. (1996) and Alessi et al. (2007)

Straczkowski et al. (2002), Bruun et al. (2004) and Fain (2010)

Yang (2005) and Graham et al. (2006)

$\uparrow o b / o b$ and $d b / d b$ mice.

$\uparrow$ Preadipocyte cell proliferation, as with TNF $\alpha$

$\uparrow$ ob/ob and $d b / d b$ mice.

$\uparrow$ In obesity, T2DM and CVD Panee (2012)

No correlation of serum

levels with obesity

although $\uparrow$ gene expression

in adipose tissue

$\uparrow$ In obesity

$\uparrow$ In obesity

$\uparrow$ In obesity, insulin resistance and T2DM

$\downarrow$ In obesity, T2DM and PCOS

$\downarrow$ In obesity
Madani et al. (2009)

Sporn et al. (1987) and Fain et al. (2005)

Kanda et al. (2006) and

Chang et al. (2011) and McGee et al. (2011) Catalán et al. (2011) and Roman et al. (2012)

Blüher (2012)

Li et al. (2010), Ramanjaneya et al. (2010) and Deniz et al. (2012)

de Souza Batista et al. (2007) 
Table 1 Continued

\begin{tabular}{ll} 
Adipokine & Function/effect \\
\cline { 1 - 2 } Apelin & $\begin{array}{l}\text { Improves insulin sensitivity } \\
\text { mainly acting in skeletal } \\
\text { muscle and adipocytes } \\
\text { in mice }\end{array}$
\end{tabular}

Distribution

Produced in a wide range of tissue
Effect of obesity

$\uparrow$ In obesity, impaired glucose tolerance and T2DM.

$\downarrow$ After weight loss following diet or bariatric surgery

\section{Evidence}

Boucher et al. (2005),

Castan-laurell et al. (2012)

AT, adipose tissue; WAT, white adipose tissue; BAT, brown adipose tissue; Sc, subcutaneous; Om, omental; T2DM, type 2 diabetes mellitus; PCOS, polycystic ovarian syndrome; CVD, cardiovascular disease; TNF $\alpha$, tumour necrosis factor $\alpha_{;}$IL6, interleukin 6; PAI-1, plasminogen activator inhibitor 1 ; IL8, interleukin 8; TGF $\beta$, transforming growth factor $\beta$; MCP1, monocyte chemotactic protein 1 ; RANTES, regulated on activation, normal T cell expressed and secreted protein; PBEF, Pre B cell colony-enhancing factor; NAMPT, nicotinamide phosphoribosyltransferase.

by increased TLR4 receptor expression as well as NF- $\kappa \mathrm{B}$ and IKK $\beta$ activity (Youssef-Elabd et al. 2012). Studies in monocytes have also shown that high-glucose conditions increased the production of IL6 and TNF $\alpha$ (Morohoshi et al. 1996), increased the mRNA and protein expression of TLR2 and TLR4 and activated the NF- $\kappa$ B pathway (Dasu et al. 2008).
Studies have further demonstrated that a change in diet, which impacts on glucose levels and subsequently lowers insulin levels, also reduces systemic inflammation (Bouché et al. 2002, Qi et al. 2006, de Mello et al. 2008, Heggen et al. 2012, Neuhouser et al. 2012). While it is established that a lower glycaemic index (GI) weight loss diet tends to reduce both the rate of absorption of glucose

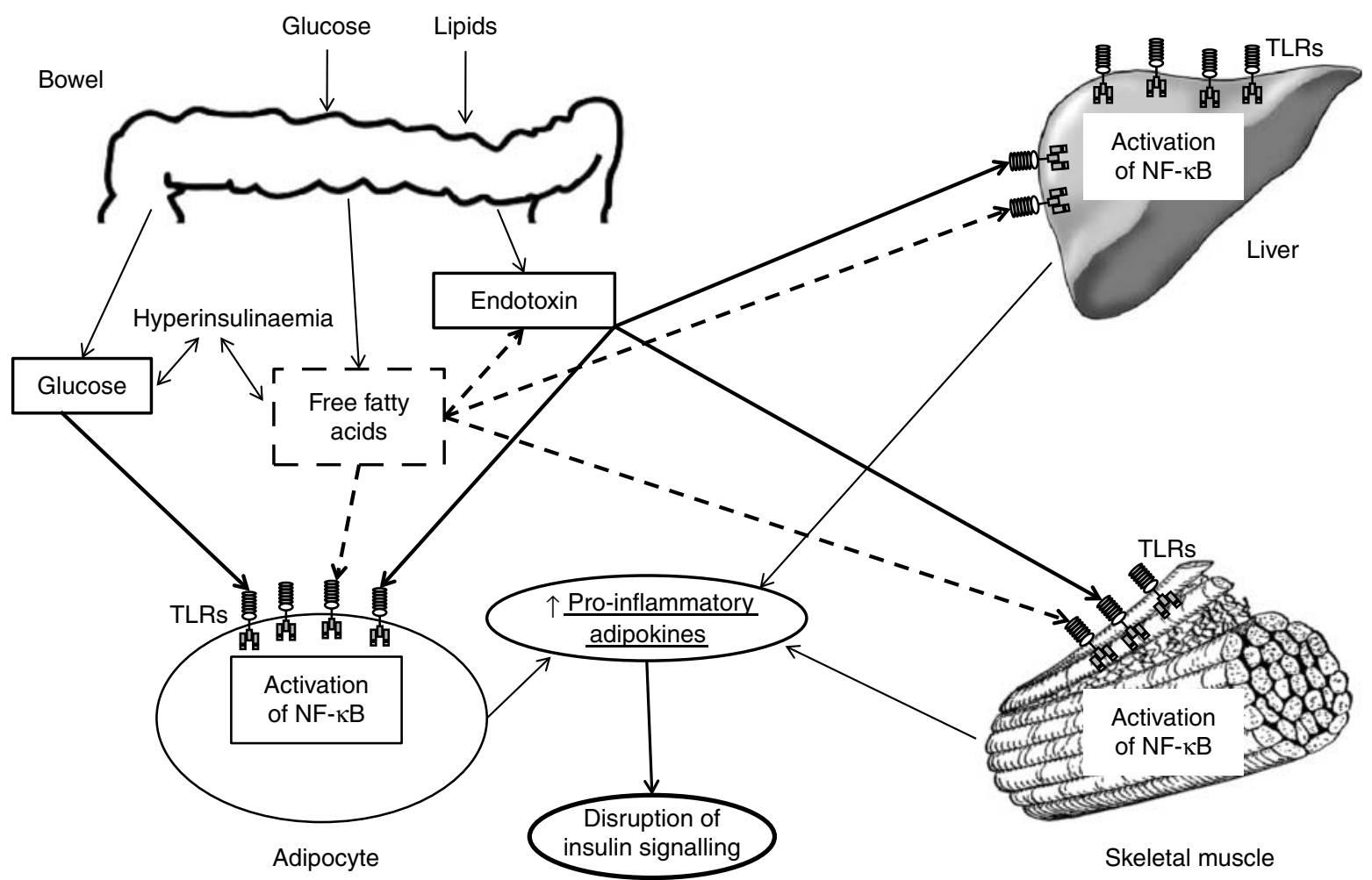

Figure 1

Overview of the effect of glucose, lipids and endotoxins on inflammation in the adipocyte, liver and skeletal muscle. Dietary glucose and lipids result in absorption of glucose, free fatty acids and leakage of endotoxins into the systemic circulation. Glucose activates NF- $\mathrm{KB}$ in the adipocytes via TLR activation, whereas free fatty acids and endotoxins activate NF- $\mathrm{KB}$ in the adipocytes, liver and skeletal muscle via TLR activation. Increased glucose results in hyperinsulinaemia, which in turn can result in an increased level of free fatty acids. Free fatty acids also have a role in increasing the endotoxin levels. Activation of NF- $\mathrm{BB}$ leads to release of proinflammatory adipokines from the adipocytes, liver and muscle, which in turn leads to disruption in insulin signalling in all three tissues, leading to insulin resistance.

Published by Bioscientifica Ltd. 
into the body and glucose load into tissue, subsequently reducing hyperinsulinaemia, there is also an observed reduction in systemic inflammation. Previous studies utilising a mouse model of obesity $(\mathrm{C} 57 \mathrm{BL} / 6 \mathrm{~J})$ have shown this, with the obese mice being fed a high-fat and either a low- or high-GI diet over 13 weeks. As such, the low-GI diet led to significant weight loss, improved glucose tolerance and insulin sensitivity. Although both diets had an equal calorie intake, the low-GI diet was accompanied by a significant reduction in systemic leptin levels and a marked rise in adiponectin levels (van Schothorst et al. 2009). Similar findings have been observed in humans with overweight/obesity, metabolic syndrome or T2DM. Where weight loss was induced via a low-GI diet, this again led to a systemic reduction in proinflammatory adipocytokines. Weight loss was shown to reduce expression of genes involved in NF- $\mathrm{KB}$ activation, which, in turn, led to improvements in insulin sensitivity (Bouché et al. 2002, Qi et al. 2006, de Mello et al. 2008, Heggen et al. 2012, Neuhouser et al. 2012).

\section{The effect of lipids on adipokine inflammation}

It is well established how vital controlling cholesterol is to reduce cardiovascular risk; the advent of statins profoundly highlighted this with a reduction in serum cholesterol being directly correlated with a marked reduction in cardiovascular risk and a reduced inflammatory profile (Pedersen et al. 2000, Hsia et al. 2011, Sever et al. 2011). More generally, lipotoxicity has been shown to play a major role in the pathogenesis of insulin resistance, with raised circulating free fatty acids associated with increased insulin resistance, as first suggested by Randle et al. (1963). Continued raised systemic free fatty acids can lead to lipid accumulation in adipose tissue and ectopic deposition of lipids, especially in the muscle and liver, which can ultimately lead to whole-body insulin resistance, this being concurrent with systemic inflammation. In muscle, the excess systemic free fatty acids are thought to mediate insulin resistance via disruption of the insulin signalling pathway via serine phosphorylation of IRS-1, as demonstrated in previous mouse model studies (Morino et al. 2008). While in the liver, excess systemic free fatty acids mediate increased intracellular diacylglycerol, which, in turn, results in lower insulinstimulated liver glycogen synthesis and decreased suppression of hepatic gluconeogenesis (Boden et al. 2005). Parallel to this, free fatty acids also appear to induce inflammation through activation of the NF- $\mathrm{kB}$ inflammatory pathway, which can mediate insulin resistance, with both inflammation and insulin resistance being alleviated by high-dose salicylates through inactivation of IKK $\beta$ (Kim et al. 2001, Yuan et al. 2001, Shoelson et al. 2003).

Studies in vitro have also enhanced our insight into the effect of fatty acids on inflammatory pathways with the downstream capacity to induce insulin resistance via proinflammatory cytokine production. Studies have suggested that saturated fatty acids (SFAs) act as ligands for several members of the TLRs leading to activation of putative inflammatory pathways (Lee et al. 2001, Lee \& Hwang 2006). This has been highlighted in several cell types such as the monocyte/macrophage cell, where SFA treatment led to activation of the innate immune pathway via TLR4 to induce downstream NF- $\mathrm{KB}$ activity as well as expression of cyclooxygenase 2 (COX2) and other inflammatory markers (Lee et al. 2001). Furthermore, in in vitro studies of human adipocytes, SFAs also activate TLR4 and NF- $\kappa B$ leading to downstream pro-inflammatory adipokine production (Youssef-Elabd et al. 2012). Similar findings for activation of TLR pathways by fatty acids have been noted in liver as well as muscle with detrimental effects (Szabo et al. 2005, Shi et al. 2006, Reyna et al. 2008, Hommelberg et al. 2010).

While more than one mechanism may induce insulin resistance, the role of the innate immune pathway appears key to how inflammation may mediate the pathogenesis of insulin resistance within different human tissues (Lee et al. 2001, Szabo et al. 2005, Lee \& Hwang 2006, Shi et al . 2006, Reyna et al. 2008, Hommelberg et al. 2010, YoussefElabd et al. 2012). Previous rodent studies have also examined the pathogenesis of insulin resistance via modulation of the innate immune pathway (Poggi et al. 2007, Tsukumo et al. 2007). Specifically, when wild-type mice and Tlr4 knockout (KO) mice were fed a high-fat diet, both maintained a similar body weight, body fat content, insulin and serum-free fatty acid levels compared with mice fed on a low-fat diet. However, the Tlr4 KO mice had lower activation of the NF-кB pathway and reduced cellular insulin resistance compared with the wild-type mice, suggesting the importance of the innate immune pathway in inducing insulin resistance (Kim et al. 2007). The effects shown in the Tlr $4 \mathrm{KO}$ mice have also been observed in Tlr3 KO mice; again these mice were fed a high-fat diet yet showed improved insulin sensitivity, lipid profile and reduced hepatic steatosis compared with wild-type mice (Wu et al. 2012b).

\section{The effect of endotoxin on adipokine inflammation}

Classically, Gram-negative bacterial fragments derived from the outer cell membrane (also referred to as LPS

Published by Bioscientifica Ltd. 
or endotoxin) have been used to stimulate an inflammatory response, as a positive control, in many in vitro experiments. It is also well documented that endotoxin stimulates the innate immunity pathway through the activation of TLRs via several proteins, including the LPS binding protein (LBP), CD14 and myeloid differential protein 2 (MD2). This leads to intracellular activation of $\mathrm{NF}-\mathrm{\kappa B}$ and resulting pro-inflammatory cytokines (Creely et al. 2007, Baker et al. 2009, Youssef-Elabd et al. 2012). However, understanding of how gut-derived endotoxin affect metabolic function has changed in recent years, as studies have considered the direct impact of endotoxin as a systemic inflammatory insult. Endotoxin is known to have a strong affinity for chylomicrons (lipoproteins that transport dietary lipids including long chain SFAs through the gut wall) and, as such, can cross the gastrointestinal mucosa coupled to damaging lipoproteins. Once in the circulation, endotoxin has been shown to mediate metabolic dysfunction in several tissues including adipose tissue, liver and muscle.

While there are several long-established risk factors that contribute to metabolic dysfunction, such as hyperglycaemia, raised triglycerides and reduced HDLcholesterol associated with insulin resistance, other 'primary inflammatory mediators' may also be relevant including endotoxin. Within this context, chronic lowgrade inflammation has been considered as another factor, coupled with obesity, insulin resistance and a raised immune response (Ouchi et al. 2011). The impact of adipose tissue on the immune response appears clear as in vitro studies, using human adipocytes, have shown that endotoxin can stimulate TLRs and NF- $\kappa$ B inflammatory pathways. This, in turn, leads to secretion of proinflammatory adipokines, with the response impacted by weight gain or loss (Creely et al. 2007, Dixon et al. 2008). In normal circumstances, only small amounts of endotoxin will cross from the intestinal lumen into the systemic circulation and the absorbed endotoxin will rapidly be removed by monocytes, particularly resident Kupffer cells within the liver. However, a compromised liver, due to ectopic fat deposition, has diminished capacity to remove the endotoxin, which can directly aggravate liver disease exacerbated by weight gain (Rao et al. 2004, Harte et al. 2010), leading to increased circulating endotoxin. Thus, a combination of dietary lipoprotein patterns and an increase in circulating endotoxin mediate chronic low-grade systemic inflammation that could activate the TLR pathway to induce downstream insulin resistance. As lipoprotein patterns would appear to alter circulating endotoxin levels, recent studies have begun to evaluate this across different insulin resistance states to examine the impact of feeding. Interestingly, a single high-fat meal did alter endotoxin levels across the different subgroups analysed. The rise in circulating endotoxin levels was $\sim 20 \%$ more in the IGT subjects and obese groups compared with the non-obese control (NOC) group, while subjects with T2DM experienced as much as $125 \%$ higher endotoxin levels than NOC, even at $4 \mathrm{~h}$ post-meal in the T2DM group (Harte et al. 2012). In addition to this, previous cross-sectional in vivo studies have shown that endotoxin appears to correlate with markers and conditions of insulin resistance, with endotoxin appearing to act as a predictive metabolic biomarker of T2DM (Dixon et al. 2008, Al-Attas et al. 2009, Miller et al. 2009, Harte et al. 2010, Pussinen et al. 2011). Taken together, the in vivo and in vitro studies highlight the impact of endotoxin on the inflammatory pathways to promote secretion of pro-inflammatory adipocytokines to exacerbate the insulin-resistant state (Brun et al. 2007, Creely et al. 2007, Dixon et al. 2008, Al-Attas et al. 2009, Baker et al. 2009, Miller et al. 2009, Harte et al. 2010, 2012).

\section{Adipokine action}

The following highlights key adipokines with Table 1 detailing a comprehensive list of adipokines along with their key functions.

Leptin was one of the first proteins discovered to be secreted from adipose tissue, by the identification and sequencing of the $o b$ gene from the $o b / o b$ mouse (Zhang et al. 1994). Daily injection of the peptide in $o b / o b$ mice resulted in a rapid reduction in food intake, body mass and percentage body fat but maintained lean muscle mass, increased energy expenditure and restored euglycaemia and reproductive function, confirming that it had an important role in energy homoeostasis and storage (Campfield et al. 1995, Halaas et al. 1995, Pelleymounter et al. 1995). However, leptin levels were noted to be increased in obese subjects, with little or no impact to regulate energy homoeostasis, which coined the wellestablished phrase 'leptin resistance' in obesity (Friedman $\&$ Halaas 1998). While this has dominated much of the literature on leptin, leptin was initially shown to have a pro-inflammatory function when studies observed that recombinant leptin activated human $\mathrm{T}$ lymphocytes and monocytes (Santos-Alvarez et al. 1999, Martín-Romero et al. 2000). More recently, leptin has also been shown to activate human B cells to secrete TNF $\alpha$, IL6 and IL10 via the JAK2, STAT3, p38MAPK and ERK signalling pathways (Agrawal et al. 2011). The pro-inflammatory nature of

Published by Bioscientifica Ltd. 
leptin has been noted in several studies, with i.v. injection of endotoxin inducing a sudden rise in leptin levels (Landman et al. 2003, Xiao et al. 2003), as well as endotoxin-induced fever and anorexia in rats, again, inducing an increase in leptin levels as part of the inflammatory response (Sachot et al. 2004).

$\mathrm{TNF} \alpha$ is a pro-inflammatory cytokine, and it was the first adipocyte-derived factor that suggested a link between obesity, inflammation and T2DM (Hotamisligil et al. 1993). Although originally thought to be mainly secreted by adipocytes, it is now thought that the majority of TNF $\alpha$ is secreted by macrophages (Weisberg et al. 2003). $\mathrm{TNF} \alpha$ is thought to play an important role in insulin resistance by reducing insulin-stimulated tyrosine phosphorylation of the insulin receptor and IRS1 in muscle and adipose tissues, but not in the liver, thus promoting insulin resistance (Hotamisligil et al. 1994). In humans, TNF $\alpha$ levels are higher in plasma and adipose tissue of subjects with obesity, and circulating levels reduce with weight loss (Kern et al. 1995, Ziccardi et al. 2002). TNFa levels were also found to positively correlate with other markers of insulin resistance (Hivert et al. 2008); nonetheless acute treatment with TNF $\alpha$ inhibitor in obese subjects with T2DM reduced other systemic inflammatory markers without reducing insulin resistance (Dominguez et al. 2005). More recently, assessment of anti-TNF $\alpha$ inhibitor treatment, over the long term, given to subjects with metabolic syndrome, has shown to improve fasting blood sugar and also increase adiponectin levels, confirming a role for TNF $\alpha$ in obesity-related insulin resistance in humans (Stanley et al. 2011).

IL6 appears to have dual functions, depending on the tissue and metabolic state. In skeletal muscle, during exercise, it acts to increase glucose uptake resulting in muscle hypertrophy and myogenesis and AMPK-mediated fatty acid oxidation, as well as having an anti-inflammatory effect (Starkie et al. 2003, Kelly et al. 2004). While in adipose tissue and hepatic tissue, IL6 is shown to be a pro-inflammatory adipokine. It increases insulin resistance by up-regulating suppressor of cytokine signalling 3 (SOCS3), which, in turn, impairs insulin-induced insulin receptor and IRS1 phosphorylation (Senn et al. 2002, 2003, Rotter et al. 2003).

IL6 is positively correlated with increasing body mass and plasma-free fatty acids (Fried et al. 1998), with reduction in circulating IL6 following weight loss (Bastard et al. 2000, Ziccardi et al. 2002). IL6 has been shown to be raised in subjects with T2DM and also increases the risk of future development of T2DM (Pradhan et al. 2001). As such, IL6 appears to have different actions that may be due to acute or chronic effects (acute exercise vs chronic release in obesity), the different tissue-specific action (liver vs muscle), or the source of IL6 (adipose tissue vs muscle), all of which appear to influence both inflammation and insulin resistance status.

Resistin is a cytokine with a molecular structure similar to adiponectin (Patel et al. 2004) and has a clear role in mice, affecting glucose homoeostasis and acting as a mediator of insulin resistance (Steppan et al. 2001, Schwartz \& Lazar 2011). However, its role in human adipose tissue has had a much more conflicted history (Nagaev \& Smith 2001, Savage et al. 2001, McTernan et al. 2002a, 2006, Schwartz \& Lazar 2011). While initially considered not be to be present in the adipocyte, subsequent studies have shown its presence and regulation (Nagaev \& Smith 2001, Savage et al. 2001, McTernan et al. 2002a,b,c, 2003, Al-Daghri et al. 2005, Baker et al. 2006, Kusminski et al. 2007), although its role in humans appears more related to an inflammatory role than being an important factor regulating glucose metabolism. In vitro studies in isolated abdominal subcutaneous adipocytes have shown an increase in resistin secretion following treatment of the adipocyte with endotoxin (LPS). In addition, treatment of adipocytes with recombinant human resistin increased release of IL6, TNF $\alpha$ as well as expression of TLR2, IKK $\beta$ and JNK, suggesting a possible role for resistin in pro-inflammatory mechanisms in the adipocyte via both the NF- $\mathrm{BB}$ and the JNK pathways (Kusminski et al. 2007).

\section{New 'kines' on the block}

The following sections represent some brief insights into recent additions to the adipokine family, which, akin to other adipokines, appear to impact on inflammation and insulin resistance.

Apelin is a peptide that is produced in a wide range of tissues with positive effects on insulin sensitivity, glucose uptake and lipolysis in skeletal muscle as well as adipose tissue (Boucher et al. 2005, Dray et al. 2008, Yue et al. 2011, Attané et al. 2012). However, studies in humans have shown an increase in plasma apelin levels in obesity, morbid obesity, impaired glucose tolerance and T2DM with a reduction in apelin levels accompanying weight loss following diet or bariatric surgery. These findings suggest the presence of resistance to apelin, in a similar fashion to insulin and leptin (Heinonen et al. 2005, Li et al. 2006, Castan-Laurell et al. 2008, Erdem et al. 2008, Soriguer et al. 2009, Zhang et al. 2009).

Published by Bioscientifica Ltd. 
Apelin has also been shown to have a pro-inflammatory role with a close positive correlation demonstrated between apelin and TNF $\alpha$ levels, as well as other proinflammatory cytokines (Malyszko et al. 2008, Heinonen et al. 2009, Yu et al. 2012). Apelin expression also closely correlates with $\mathrm{TNF} \alpha$ in adipose tissue of lean and obese individuals, and in vitro studies of cultured human adipose tissue explants show an up-regulation of apelin in response to TNF $\alpha$ (Daviaud et al. 2006). Further in vitro studies in human umbilical vein endothelial cells (HUVECs) suggest an increase in adhesion molecules (VCAM and ICAM) by apelin via the NF- $\mathrm{B}$ and JNK pathways, further supporting its role as a pro-inflammatory adipokine (Lu et al. 2012).

Omentin is another new peptide that is produced in omental but not subcutaneous adipose tissue and exists in two isoforms, omentin 1 and omentin 2. Omentin 1 represents the predominant circulating form and positively affects insulin sensitivity, which is reduced in subjects with obesity and T2DM compared with lean subjects (de Souza Batista et al. 2007, Shibata et al. 2012). Omentin is thought to be an anti-inflammatory adipokine and acts by inhibiting TNF $\alpha$-induced expression of adhesion molecules in endothelial cells by inhibiting the ERK/NF- $\kappa \mathrm{B}$ pathway (Zhong et al. 2012), while in vascular smooth muscle cells omentin inhibits TNF $\alpha$ action via inhibition of p38 and JNK pathways (Kazama et al. 2012). Taken together, this suggests that omentin may have a positive role to play to reduce inflammation in normal physiology.

Chemerin is a novel adipokine that has been shown to play a role in the regulation of adipogenesis and adipocyte metabolism (Goralski et al. 2007), as well as a role in glucose homoeostasis - as noted by studies on glucose intolerance in $o b / o b$ and $d b / d b$ mice (Ernst et al. 2010). In humans, however, chemerin seems to have a direct action on inflammation in adipocytes rather than glucose homoeostasis, as use of recombinant $\mathrm{TNF} \alpha$ seems to induce chemerin secretion from adipocytes (Catalán et al. 2011). In other inflammatory cell types, such as macrophages, chemerin causes a pro-inflammatory action through increasing macrophage adhesion to VCAM-1 and fibronectin (Hart \& Greaves 2010). As such, in subsequently considered coronary artery disease patients, where inflammation had progressed, circulating chemerin levels were noted to be positively correlated with multiple markers of inflammation including TNF $\alpha$, IL6, C-reactive protein (CRP), leptin and resistin, affirming its proinflammatory function (Lehrke et al. 2009). In separate studies of T2DM subjects at risk of CVD, analysis of their circulating chemerin levels also revealed positive associations with inflammatory markers, including TNF $\alpha$ CRP, leptin and resistin (Weigert et al. 2010, Yu et al. 2012). These combined studies indicate a pro-inflammatory function for chemerin, which appears exacerbated in metabolic disease states.

\section{Conclusion}

This current review has examined the importance of inflammatory pathways that can impact on adipokine function leading to insulin resistance. It is clear that through 'overnutrition', glucose, lipids and endotoxin can affect different tissues to mediate an aberrant inflammatory response and advance the pathogenesis of insulin resistance and metabolic disease. While it is evident that adiposity exacerbates this developing inflammatory state, compromised further by ectopic fat disposition, it is, perhaps, the continual insults from our dysfunctional diets that provide the key targets for intervention. Reducing the burden of inflammatory insults on our adipose tissue may subsequently impact on our long-term health to reduce the encumbrance of metabolic disease.

\section{Declaration of interest}

The authors declare that there is no conflict of interest that could be perceived as prejudicing the impartiality of the review.

\section{Funding}

This research did not receive any specific grant from any funding agency in the public, commercial or not-for-profit sector.

\section{Acknowledgements}

The authors would like to acknowledge University Hospitals Coventry and Warwickshire NHS Trust and Birmingham Science City.

\section{References}

Agrawal S, Gollapudi S, Su H \& Gupta S 2011 Leptin activates human B cells to secrete TNF- $\alpha$, IL-6, and IL-10 via JAK2/STAT3 and p38MAPK/ERK1/2 signaling pathway. Journal of Clinical Immunology 31 472-478. (doi:10. 1007/s10875-010-9507-1)

Al-Attas OS, Al-Daghri NM, Al-Rubeaan K, da Silva NF, Sabico SL, Kumar S, McTernan PG \& Harte AL 2009 Changes in endotoxin levels in T2DM subjects on anti-diabetic therapies. Cardiovascular Diabetology 820. (doi:10.1186/1475-2840-8-20)

Al-Daghri N, Chetty R, McTernan PG, Al-Rubean K, Al-Attas O, Jones AF \& Kumar S 2005 Serum resistin is associated with C-reactive protein \& LDL cholesterol in type 2 diabetes and coronary artery disease in a Saudi population. Cardiovascular Diabetology 4 10. (doi:10.1186/14752840-4-10) 
Alessi MC, Poggi M \& Juhan-Vague I 2007 Plasminogen activator inhibitor1, adipose tissue and insulin resistance. Current Opinion in Lipidology 18 240-245. (doi:10.1097/MOL.0b013e32814e6d29)

Attané C, Foussal C, Le Gonidec S, Benani A, Daviaud D, Wanecq E, Guzmán-Ruiz R, Dray C, Bezaire V, Rancoule C et al. 2012 Apelin treatment increases complete fatty acid oxidation, mitochondrial oxidative capacity, and biogenesis in muscle of insulin-resistant mice. Diabetes 61 310-320. (doi:10.2337/db11-0100)

Baker AR, Silva NF, Quinn DW, Harte AL, Pagano D, Bonser RS, Kumar S \& McTernan PG 2006 Human epicardial adipose tissue expresses a pathogenic profile of adipocytokines in patients with cardiovascular disease. Cardiovascular Diabetology 5 1. (doi:10.1186/1475-2840-5-1)

Baker AR, Harte AL, Howell N, Pritlove DC, Ranasinghe AM, da Silva NF, Youssef EM, Khunti K, Davies MJ, Bonser RS et al. 2009 Epicardial adipose tissue as a source of nuclear factor-kappaB and c-Jun N-terminal kinase mediated inflammation in patients with coronary artery disease. Journal of Clinical Endocrinology and Metabolism 94 261-267. (doi:10.1210/jc.2007-2579)

Bastard JP, Jardel C, Bruckert E, Blondy P, Capeau J, Laville M, Vidal H \& Hainque B 2000 Elevated levels of interleukin 6 are reduced in serum and subcutaneous adipose tissue of obese women after weight loss. Journal of Clinical Endocrinology and Metabolism 85 3338-3342. (doi:10.1210/jc.85.9.3338)

Berrington de Gonzalez A, Hartge P, Cerhan JR, Flint AJ, Hannan L, MacInnis RJ, Moore SC, Tobias GS, Anton-Culver H, Freeman LB et al. 2010 Body-mass index and mortality among 1.46 million white adults. New England Journal of Medicine 363 2211-2219. (doi:10.1056/ NEJMoa1000367)

Blüher M 2012 Vaspin in obesity and diabetes: pathophysiological and clinical significance. Endocrine 41 176-182. (doi:10.1007/s12020011-9572-0)

Boden G, She P, Mozzoli M, Cheung P, Gumireddy K, Reddy P, Xiang X, Luo Z \& Ruderman N 2005 Free fatty acids produce insulin resistance and activate the proinflammatory nuclear factor-kappaB pathway in rat liver. Diabetes 54 3458-3465. (doi:10.2337/diabetes.54.12.3458)

Bouché C, Rizkalla SW, Luo J, Vidal H, Veronese A, Pacher N, Fouquet C, Lang V \& Slama G 2002 Five-week, low-glycemic index diet decreases total fat mass and improves plasma lipid profile in moderately overweight nondiabetic men. Diabetes Care 25 822-828. (doi:10.2337/ diacare.25.5.822)

Boucher J, Masri B, Daviaud D, Gesta S, Guigne C, Mazzucotelli A, Castan-Laurell I, Tack I, Knibiehler B, Carpene C et al. 2005 Apelin, a newly identified adipokine up-regulated by insulin and obesity. Endocrinology 146 1764-1771. (doi:10.1210/en.2004-1427)

Brun P, Castagliuolo I, Di Leo V, Buda A, Pinzani M, Palù G \& Martines D 2007 Increased intestinal permeability in obese mice: new evidence in the pathogenesis of nonalcoholic steatohepatitis. American Journal of Physiology. Gastrointestinal and Liver Physiology 292 G518-G525. (doi:10.1152/ajpgi.00024.2006)

Bruun JM, Lihn AS, Madan AK, Pedersen SB, Schiøtt KM, Fain JN \& Richelsen B 2004 Higher production of IL-8 in visceral vs. subcutaneous adipose tissue. Implication of nonadipose cells in adipose tissue. American Journal of Physiology. Endocrinology and Metabolism 286 E8-13. (doi:10.1152/ajpendo.00269.2003)

Campfield LA, Smith FJ, Guisez Y, Devos R \& Burn P 1995 Recombinant mouse $\mathrm{OB}$ protein: evidence for a peripheral signal linking adiposity and central neural networks. Science 269 546-549. (doi:10.1126/ science.7624778)

Carobbio S, Rodriguez-Cuenca S \& Vidal-Puig A 2011 Origins of metabolic complications in obesity: ectopic fat accumulation. The importance of the qualitative aspect of lipotoxicity. Current Opinion in Clinical Nutrition and Metabolic Care 14 520-526. (doi:10.1097/MCO. Ob013e32834ad966)

Castan-Laurell I, Vítkova M, Daviaud D, Dray C, Kováciková M, Kovacova Z, Hejnova J, Stich V \& Valet P 2008 Effect of hypocaloric diet-induced weight loss in obese women on plasma apelin and adipose tissue expression of apelin and APJ. European Journal of Endocrinology 158 905-910. (doi:10.1530/EJE-08-0039)

Castan-laurell I, Dray C, Knauf C, Kunduzova O \& Valet P 2012 Apelin, a promising target for type 2 diabetes treatment? Trends in Endocrinology and Metabolism 23 234-241. (doi:10.1016/j.tem.2012.02.005)

Catalán V, Gómez-Ambrosi J, Rodríguez A, Ramírez B, Rotellar F, Valentí V, Silva C, Gil MJ, Salvador J \& Frühbeck G 2013 Increased levels of chemerin and its receptor, chemokine-like receptor-1, in obesity are related to inflammation: tumor necrosis factor- $\alpha$ stimulates mRNA levels of chemerin in visceral adipocytes from obese patients. Surgery for Obesity and Related Diseases In press. (doi:10.1016/j.soard.2011. 11.001)

Chang YH, Chang DM, Lin KC, Shin SJ \& Lee YJ 2011 Visfatin in overweight/obesity, type 2 diabetes mellitus, insulin resistance, metabolic syndrome and cardiovascular diseases: a meta-analysis and systemic review. Diabetes/Metabolism Research and Reviews 27 515-527. (doi:10.1002/dmrr.1201)

Couillard C, Lamarche B, Tchernof A, Prud'homme D, Tremblay A, Bouchard C, Moorjani S, Nadeau A, Lupien PJ \& Després JP 1996 Plasma high-density lipoprotein cholesterol but not apolipoprotein A-I is a good correlate of the visceral obesity-insulin resistance dyslipidemic syndrome. Metabolism 45 882-888. (doi:10.1016/S0026-0495(96) 90164-X)

Creely SJ, McTernan PG, Kusminski CM, Fisher M, Da Silva NF, Khanolkar M, Evans M, Harte AL \& Kumar S 2007 Lipopolysaccharide activates an innate immune system response in human adipose tissue in obesity and type 2 diabetes. American Journal of Physiology. Endocrinology and Metabolism 292 E740-E747. (doi:10.1152/ajpendo.00302.2006)

Cypess AM, Lehman S, Williams G, Tal I, Rodman D, Goldfine AB, Kuo FC, Palmer EL, Tseng Y-H, Doria A et al. 2009 Identification and importance of brown adipose tissue in adult humans. New England Journal of Medicine 360 1509-1517. (doi:10.1056/NEJMoa0810780)

Czernichow S, Kengne AP, Stamatakis E, Hamer M \& Batty GD 2011 Body mass index, waist circumference and waist-hip ratio: which is the better discriminator of cardiovascular disease mortality risk?: evidence from an individual-participant meta-analysis of 82864 participants from nine cohort studies Obesity Reviews 12 680-687. (doi:10.1111/ j.1467-789X.2011.00879.x)

Dandona P, Chaudhuri A, Ghanim H \& Mohanty P 2007 Proinflammatory effects of glucose and anti-inflammatory effect of insulin: relevance to cardiovascular disease. American Journal of Cardiology 99 15B-26B. (doi:10.1016/j.amjcard.2006.11.003)

Dasu MR, Devaraj S, Zhao L, Hwang DH \& Jialal I 2008 High glucose induces Toll-like receptor expression in human monocytes: mechanism of activation. Diabetes 57 3090-3098. (doi:10.2337/db08-0564)

Daviaud D, Boucher J, Gesta S, Dray C, Guigne C, Quilliot D, Ayav A, Ziegler O, Carpene C, Saulnier-Blache JS et al. 2006 TNF $\alpha$ up-regulates apelin expression in human and mouse adipose tissue. FASEB Journal 20 1528-1530. (doi:10.1096/fj.05-5243fje)

Deniz R, Gurates B, Aydin S, Celik H, Sahin I, Baykus Y, Catak Z, Aksoy A, Citil C \& Gungor S 2012 Nesfatin-1 and other hormone alterations in polycystic ovary syndrome. Endocrine 42 694-699. (doi:10.1007/ s12020-012-9638-7)

Després JP, Moorjani S, Lupien PJ, Tremblay A, Nadeau A \& Bouchard C 1990 Regional distribution of body fat, plasma lipoproteins, and cardiovascular disease. Arteriosclerosis 10 497-511. (doi:10.1161/01. ATV.10.4.497)

Després JP, Couillard C, Gagnon J, Bergeron J, Leon AS, Rao DC, Skinner JS, Wilmore JH \& Bouchard C 2000 Race, visceral adipose tissue, plasma lipids, and lipoprotein lipase activity in men and women: the Health, Risk Factors, Exercise Training, and Genetics (HERITAGE) family study. Arteriosclerosis, Thrombosis, and Vascular Biology 20 1932-1938. (doi:10.1161/01.ATV.20.8.1932)

Diop SB \& Bodmer R 2012 Drosophila as a model to study the genetic mechanisms of obesity-associated heart dysfunction. Journal of Cellular

Published by Bioscientifica Ltd. 
and Molecular Medicine 16 966-971. (doi:10.1111/j.1582-4934.2012. 01522.x)

Dixon AN, Valsamakis G, Hanif MW, Field A, Boutsiadis A, Harte A, McTernan PG, Barnett AH \& Kumar S 2008 Effect of the orlistat on serum endotoxin lipopolysaccharide and adipocytokines in South Asian individuals with impaired glucose tolerance. International Journal of Clinical Practice 62 1124-1129. (doi:10.1111/j.1742-1241. 2008.01800.x)

Dominguez H, Storgaard H, Rask-Madsen C, Steffen Hermann T, Ihlemann N, Baunbjerg Nielsen D, Spohr C, Kober L, Vaag A \& Torp-Pedersen C 2005 Metabolic and vascular effects of tumor necrosis factor- $\alpha$ blockade with etanercept in obese patients with type 2 diabetes. Journal of Vascular Research 42 517-525. (doi:10.1159/000088261)

Dray C, Knauf C, Daviaud D, Waget A, Boucher J, Buléon M, Cani PD, Attané C, Guigné C, Carpéné C et al. 2008 Apelin stimulates glucose utilization in normal and obese insulin-resistant mice. Cell Metabolism 8 437-445. (doi:10.1016/j.cmet.2008.10.003)

Eder K, Baffy N, Falus A \& Fulop AK 2009 The major inflammatory mediator interleukin-6 and obesity. Inflammation Research $\mathbf{5 8}$ 727-736. (doi:10.1007/s00011-009-0060-4)

Erdem G, Dogru T, Tasci I, Sonmez A \& Tapan S 2008 Low plasma apelin levels in newly diagnosed type 2 diabetes mellitus. Experimental and Clinical Endocrinology \& Diabetes 116 289-292. (doi:10.1055/s-20071004564)

Ernst MC, Issa M, Goralski KB \& Sinal CJ 2010 Chemerin exacerbates glucose intolerance in mouse models of obesity and diabetes. Endocrinology 151 1998-2007. (doi:10.1210/en.2009-1098)

Esposito K, Nappo F, Marfella R, Giugliano G, Giugliano F, Ciotola M, Quagliaro L, Ceriello A \& Giugliano D 2002 Inflammatory cytokine concentrations are acutely increased by hyperglycemia in humans: role of oxidative stress. Circulation 106 2067-2072. (doi:10.1161/01.CIR. 0000034509.14906.AE)

Fain JN 2010 Release of inflammatory mediators by human adipose tissue is enhanced in obesity and primarily by the nonfat cells: a review. Mediators of Inflammation 2010 513948. (doi:10.1155/2010/ 513948)

Fain JN, Tichansky DS \& Madan AK 2005 Transforming growth factor $\beta 1$ release by human adipose tissue is enhanced in obesity. Metabolism $\mathbf{5 4}$ 1546-1551. (doi:10.1016/j.metabol.2005.05.024)

Fisher FM, McTernan PG, Valsamakis G, Chetty R, Harte AL, Anwar AJ, Starcynski J, Crocker J, Barnett AH, McTernan CL et al. 2002 Differences in adiponectin protein expression: effect of fat depots and type 2 diabetic status. Hormone and Metabolic Research 34 650-654. (doi:10. 1055/s-2002-38246)

Fried SK, Bunkin DA \& Greenberg AS 1998 Omental and subcutaneous adipose tissues of obese subjects release interleukin-6: depot difference and regulation by glucocorticoid. Journal of Clinical Endocrinology and Metabolism 83 847-850. (doi:10.1210/jc.83.3.847)

Friedman JM \& Halaas JL 1998 Leptin and the regulation of body weight in mammals. Nature 395 763-770. (doi:10.1038/27376)

Frühbeck G, Gómez-Ambrosi J, Muruzábal FJ \& Burrell MA 2001 The adipocyte: a model for integration of endocrine and metabolic signaling in energy metabolism regulation. American Journal of Physiology. Endocrinology and Metabolism 280 E827-E847.

Gerstein HC, Pogue J, Mann JF, Lonn E, Dagenais GR, McQueen M, Yusuf S \& investigators H 2005 The relationship between dysglycaemia and cardiovascular and renal risk in diabetic and non-diabetic participants in the HOPE study: a prospective epidemiological analysis. Diabetologia 48 1749-1755. (doi:10.1007/s00125-005-1858-4)

Ghanim H, Mohanty P, Deopurkar R, Sia CL, Korzeniewski K, Abuaysheh S, Chaudhuri A \& Dandona P 2008 Acute modulation of Toll-like receptors by insulin. Diabetes Care 31 1827-1831. (doi:10.2337/ dc08-0561)

Goralski KB, McCarthy TC, Hanniman EA, Zabel BA, Butcher EC, Parlee SD, Muruganandan S \& Sinal CJ 2007 Chemerin, a novel adipokine that regulates adipogenesis and adipocyte metabolism. Journal of Biological Chemistry 282 28175-28188. (doi:10.1074/jbc.M700793200)

Graham TE, Yang Q, Blüher M, Hammarstedt A, Ciaraldi TP, Henry RR, Wason CJ, Oberbach A, Jansson PA, Smith U et al. 2006 Retinol-binding protein 4 and insulin resistance in lean, obese, and diabetic subjects. New England Journal of Medicine 354 2552-2563. (doi:10.1056/ NEJMoa054862)

Halaas JL, Gajiwala KS, Maffei M, Cohen SL, Chait BT, Rabinowitz D, Lallone RL, Burley SK \& Friedman JM 1995 Weight-reducing effects of the plasma protein encoded by the obese gene. Science 269 543-546. (doi:10.1126/science.7624777)

Hart R \& Greaves DR 2010 Chemerin contributes to inflammation by promoting macrophage adhesion to VCAM-1 and fibronectin through clustering of VLA-4 and VLA-5. Journal of Immunology 185 3728-3739. (doi:10.4049/jimmunol.0902154)

Harte AL, McTernan PG, McTernan CL, Crocker J, Starcynski J, Barnett AH, Matyka K \& Kumar S 2003a Insulin increases angiotensinogen expression in human abdominal subcutaneous adipocytes. Diabetes, Obesity \& Metabolism 5 462-467. (doi:10.1046/j.1463-1326. 2003.00274.x)

Harte AL, McTernan PG, McTernan CL, Smith SA, Barnett AH \& Kumar S $2003 b$ Rosiglitazone inhibits the insulin-mediated increase in PAI-1 secretion in human abdominal subcutaneous adipocytes. Diabetes, Obesity \& Metabolism 5 302-310. (doi:10.1046/j.1463-1326. 2003.00276.x)

Harte AL, da Silva NF, Creely SJ, McGee KC, Billyard T, Youssef-Elabd EM, Tripathi G, Ashour E, Abdalla MS, Sharada HM et al. 2010 Elevated endotoxin levels in non-alcoholic fatty liver disease. Journal of Inflammation 7 15. (doi:10.1186/1476-9255-7-15)

Harte AL, Varma MC, Tripathi G, McGee KC, Al-Daghri NM, Al-Attas OS, Sabico S, O'Hare JP, Ceriello A, Saravanan P et al. 2012 High fat intake leads to acute postprandial exposure to circulating endotoxin in type 2 diabetic subjects. Diabetes Care 35 375-382. (doi:10.2337/ dc11-1593)

Heggen E, Klemsdal TO, Haugen F, Holme I \& Tonstad S 2012 Effect of a low-fat versus a low-gycemic-load diet on inflammatory biomarker and adipokine concentrations. Metabolic Syndrome and Related Disorders 10 437-442. (doi:10.1089/met.2012.0012)

Heinonen MV, Purhonen AK, Miettinen P, Pääkkönen M, Pirinen E, Alhava E, Åkerman K \& Herzig KH 2005 Apelin, orexin-A and leptin plasma levels in morbid obesity and effect of gastric banding. Regulatory Peptides 130 7-13. (doi:10.1016/j.regpep.2005.05.003)

Heinonen MV, Laaksonen DE, Karhu T, Karhunen L, Laitinen T, Kainulainen S, Rissanen A, Niskanen L \& Herzig KH 2009 Effect of dietinduced weight loss on plasma apelin and cytokine levels in individuals with the metabolic syndrome. Nutrition, Metabolism, and Cardiovascular Diseases 19 626-633. (doi:10.1016/j.numecd.2008.12.008)

Hivert MF, Sullivan LM, Fox CS, Nathan DM, D'Agostino RB, Wilson PW \& Meigs JB 2008 Associations of adiponectin, resistin, and tumor necrosis factor- $\alpha$ with insulin resistance. Journal of Clinical Endocrinology and Metabolism 93 3165-3172. (doi:10.1210/jc.2008-0425)

Hommelberg PP, Langen RC, Schols AM, Mensink RP \& Plat J 2010 Inflammatory signaling in skeletal muscle insulin resistance: green signal for nutritional intervention? Current Opinion in Clinical Nutrition and Metabolic Care 13 647-655. (doi:10.1097/MCO.0b013e32833f1acd)

Hotamisligil GS 2006 Inflammation and metabolic disorders. Nature $\mathbf{4 4 4}$ 860-867. (doi:10.1038/nature05485)

Hotamisligil GS, Shargill NS \& Spiegelman BM 1993 Adipose expression of tumor necrosis factor- $\alpha$ : direct role in obesity-linked insulin resistance. Science 259 87-91. (doi:10.1126/science.7678183)

Hotamisligil GS, Budavari A, Murray D \& Spiegelman BM 1994 Reduced tyrosine kinase activity of the insulin receptor in obesity-diabetes. Central role of tumor necrosis factor- $\alpha$. Journal of Clinical Investigation 94 1543-1549. (doi:10.1172/JCI117495)

Hsia J, MacFadyen JG, Monyak J \& Ridker PM 2011 Cardiovascular event reduction and adverse events among subjects attaining low-density 
lipoprotein cholesterol $<50 \mathrm{mg} / \mathrm{dl}$ with rosuvastatin. The JUPITER trial (Justification for the Use of Statins in Prevention: an Intervention Trial Evaluating Rosuvastatin). Journal of the American College of Cardiology $\mathbf{5 7}$ 1666-1675. (doi:10.1016/j.jacc.2010.09.082)

Hube F \& Hauner H 1999 The role of TNF- $\alpha$ in human adipose tissue: prevention of weight gain at the expense of insulin resistance? Hormone and Metabolic Research 31 626-631. (doi:10.1055/s-2007-978810)

Jernås M, Olsson B, Arner P, Jacobson P, Sjöström L, Walley A, Froguel P, McTernan PG, Hoffstedt J \& Carlsson LM 2009 Regulation of carboxylesterase 1 (CES1) in human adipose tissue. Biochemical and Biophysical Research Communications 383 63-67. (doi:10.1016/j.bbrc. 2009.03.120)

Kalupahana NS, Moustaid-Moussa N \& Claycombe KJ 2012 Immunity as a link between obesity and insulin resistance. Molecular Aspects of Medicine 33 26-34. (doi:10.1016/j.mam.2011.10.011)

Kanda H, Tateya S, Tamori Y, Kotani K, Hiasa K, Kitazawa R, Kitazawa S, Miyachi H, Maeda S, Egashira K et al. 2006 MCP-1 contributes to macrophage infiltration into adipose tissue, insulin resistance, and hepatic steatosis in obesity. Journal of Clinical Investigation 116 1494-1505. (doi:10.1172/JCI26498)

Kazama K, Usui T, Okada M, Hara Y \& Yamawaki H 2012 Omentin plays an anti-inflammatory role through inhibition of TNF- $\alpha$-induced superoxide production in vascular smooth muscle cells. European Journal of Pharmacology 686 116-123. (doi:10.1016/j.ejphar.2012.04.033)

Kelly M, Keller C, Avilucea PR, Keller P, Luo Z, Xiang X, Giralt M, Hidalgo J, Saha AK, Pedersen BK et al. 2004 AMPK activity is diminished in tissues of IL-6 knockout mice: the effect of exercise. Biochemical and Biophysical Research Communications 320 449-454. (doi:10.1016/j.bbrc. 2004.05.188)

Kern PA, Saghizadeh M, Ong JM, Bosch RJ, Deem R \& Simsolo RB 1995 The expression of tumor necrosis factor in human adipose tissue. Regulation by obesity, weight loss, and relationship to lipoprotein lipase. Journal of Clinical Investigation 95 2111-2119. (doi:10.1172/ JCI117899)

Kim JK, Kim YJ, Fillmore JJ, Chen Y, Moore I, Lee J, Yuan M, Li ZW, Karin M, Perret P et al. 2001 Prevention of fat-induced insulin resistance by salicylate. Journal of Clinical Investigation 108 437-446. (doi:10.1172/ JCI11559)

Kim F, Pham M, Luttrell I, Bannerman DD, Tupper J, Thaler J, Hawn TR, Raines EW \& Schwartz MW 2007 Toll-like receptor-4 mediates vascular inflammation and insulin resistance in diet-induced obesity. Circulation Research 100 1589-1596. (doi:10.1161/CIRCRESAHA.106.142851)

Kos K, Harte AL, James S, Snead DR, O'Hare JP, McTernan PG \& Kumar S 2007 Secretion of neuropeptide $\mathrm{Y}$ in human adipose tissue and its role in maintenance of adipose tissue mass. American Journal of Physiology. Endocrinology and Metabolism 293 E1335-E1340. (doi:10.1152/ajpendo. 00333.2007)

Kos K, Harte AL, O’Hare PJ, Kumar S \& McTernan PG 2009 Ghrelin and the differential regulation of des-acyl (DSG) and oct-anoyl ghrelin (OTG) in human adipose tissue (AT). Clinical Endocrinology 70 383-389. (doi:10.1111/j.1365-2265.2008.03321.x)

Koster A, Leitzmann MF, Schatzkin A, Mouw T, Adams KF, van Eijk JT, Hollenbeck AR \& Harris TB 2008 Waist circumference and mortality. American Journal of Epidemiology 167 1465-1475. (doi:10.1093/aje/ kwn079)

Kühnlein RP 2010 Drosophila as a lipotoxicity model organism - more than a promise? Biochimica et Biophysica Acta 1801 215-221. (doi:10.1016/j. bbalip.2009.09.006)

Kusminski CM, da Silva NF, Creely SJ, Fisher FM, Harte AL, Baker AR, Kumar S $\&$ McTernan PG 2007 The in vitro effects of resistin on the innate immune signaling pathway in isolated human subcutaneous adipocytes. Journal of Clinical Endocrinology and Metabolism 92 270-276. (doi:10.1210/ jc.2006-1151)

Landman RE, Puder JJ, Xiao E, Freda PU, Ferin M \& Wardlaw SL 2003 Endotoxin stimulates leptin in the human and nonhuman primate.
Journal of Clinical Endocrinology and Metabolism 88 1285-1291. (doi:10.1210/jc.2002-021393)

Lee JY \& Hwang DH 2006 The modulation of inflammatory gene expression by lipids: mediation through Toll-like receptors. Molecules and Cells 21 174-185.

Lee JY, Sohn KH, Rhee SH \& Hwang D 2001 Saturated fatty acids, but not unsaturated fatty acids, induce the expression of cyclooxygenase-2 mediated through Toll-like receptor 4. Journal of Biological Chemistry 276 16683-16689. (doi:10.1074/jbc.M011695200)

Lehrke M, Becker A, Greif M, Stark R, Laubender RP, von Ziegler F, Lebherz C, TittusJ, Reiser M, Becker C et al. 2009 Chemerin is associated with markers of inflammation and components of the metabolic syndrome but does not predict coronary atherosclerosis. European Journal of Endocrinology 161 339-344. (doi:10.1530/EJE-09-0380)

Li L, Yang G, Li Q, Tang Y, Yang M, Yang H \& Li K 2006 Changes and relations of circulating visfatin, apelin, and resistin levels in normal, impaired glucose tolerance, and type 2 diabetic subjects. Experimental and Clinical Endocrinology \& Diabetes 114 544-548. (doi:10.1055/s-2006948309)

Li QC, Wang HY, Chen X, Guan HZ \& Jiang ZY 2010 Fasting plasma levels of nesfatin- 1 in patients with type 1 and type 2 diabetes mellitus and the nutrient-related fluctuation of nesfatin-1 level in normal humans. Regulatory Peptides 159 72-77. (doi:10.1016/j.regpep.2009.11.003)

Lu Y, Zhu X, Liang GX, Cui RR, Liu Y, Wu SS, Liang QH, Liu GY, Jiang Y, Liao XB et al. 2012 Apelin-APJ induces ICAM-1, VCAM-1 and MCP-1 expression via NF- $\mathrm{kB} / \mathrm{JNK}$ signal pathway in human umbilical vein endothelial cells. Amino Acids 43 2125-2136. (doi:10.1007/s00726-0121298-7)

Madani R, Karastergiou K, Ogston NC, Miheisi N, Bhome R, Haloob N, Tan GD, Karpe F, Malone-Lee J, Hashemi M et al. 2009 RANTES release by human adipose tissue in vivo and evidence for depot-specific differences. American Journal of Physiology. Endocrinology and Metabolism 296 E1262-E1268. (doi:10.1152/ajpendo.90511.2008)

Malyszko J, Malyszko JS, Pawlak K, Wolczynski S \& Mysliwiec M 2008 Apelin, a novel adipocytokine, in relation to endothelial function and inflammation in kidney allograft recipients. Transplantation Proceedings 40 3466-3469. (doi:10.1016/j.transproceed.2008.06.059)

Manolopoulos KN, Karpe F \& Frayn KN 2010 Gluteofemoral body fat as a determinant of metabolic health. International Journal of Obesity $\mathbf{3 4}$ 949-959. (doi:10.1038/ijo.2009.286)

Mantzoros CS, Magkos F, Brinkoetter M, Sienkiewicz E, Dardeno TA, Kim SY, Hamnvik OP \& Koniaris A 2011 Leptin in human physiology and pathophysiology. American Journal of Physiology. Endocrinology and Metabolism 301 E567-E584. (doi:10.1152/ajpendo.00315.2011)

van Marken Lichtenbelt WD, Vanhommerig JW, Smulders NM, Drossaerts JMAFL, Kemerink GJ, Bouvy ND, Schrauwen P \& Teule GJJ 2009 Cold-activated brown adipose tissue in healthy men. New England Journal of Medicine 360 1500-1508. (doi:10.1056/NEJMoa0808718)

Martín-Romero C, Santos-Alvarez J, Goberna R \& Sánchez-Margalet V 2000 Human leptin enhances activation and proliferation of human circulating T lymphocytes. Cellular Immunology 199 15-24. (doi:10.1006/cimm.1999.1594)

McGee KC, Harte AL, da Silva NF, Al-Daghri N, Creely SJ, Kusminski CM, Tripathi G, Levick PL, Khanolkar M, Evans M et al. 2011 Visfatin is regulated by rosiglitazone in type 2 diabetes mellitus and influenced by NFKB and JNK in human abdominal subcutaneous adipocytes. PLoS ONE 6 e20287. (doi:10.1371/journal.pone.0020287)

McTernan CL, McTernan PG, Harte AL, Levick PL, Barnett AH \& Kumar S $2002 a$ Resistin, central obesity, and type 2 diabetes. Lancet 359 46-47. (doi:10.1016/S0140-6736(02)07281-1)

McTernan PG, Harte AL, Anderson LA, Green A, Smith SA, Holder JC, Barnett AH, Eggo MC \& Kumar S 2002b Insulin and rosiglitazone regulation of lipolysis and lipogenesis in human adipose tissue in vitro. Diabetes 51 1493-1498. (doi:10.2337/diabetes.51.5.1493)

McTernan PG, McTernan CL, Chetty R, Jenner K, Fisher FM, Lauer MN, Crocker J, Barnett AH \& Kumar S 2002c Increased resistin 
gene and protein expression in human abdominal adipose tissue. Journal of Clinical Endocrinology and Metabolism 87 2407. (doi:10.1210/ jc.87.5.2407)

McTernan PG, Fisher FM, Valsamakis G, Chetty R, Harte A, McTernan CL, Clark PM, Smith SA, Barnett AH \& Kumar S 2003 Resistin and type 2 diabetes: regulation of resistin expression by insulin and rosiglitazone and the effects of recombinant resistin on lipid and glucose metabolism in human differentiated adipocytes. Journal of Clinical Endocrinology and Metabolism 88 6098-6106. (doi:10.1210/jc.2003-030898)

McTernan PG, Kusminski CM \& Kumar S 2006 Resistin. Current Opinion in Lipidology 17 170-175. (doi:10.1097/01.mol.0000217899.59820.9a)

Meier U \& Gressner AM 2004 Endocrine regulation of energy metabolism: review of pathobiochemical and clinical chemical aspects of leptin, ghrelin, adiponectin, and resistin. Clinical Chemistry 50 1511-1525. (doi:10.1373/clinchem.2004.032482)

de Mello VD, Kolehmainen M, Pulkkinen L, Schwab U, Mager U, Laaksonen DE, Niskanen L, Gylling H, Atalay M, Rauramaa R et al. 2008 Downregulation of genes involved in NFkappaB activation in peripheral blood mononuclear cells after weight loss is associated with the improvement of insulin sensitivity in individuals with the metabolic syndrome: the GENOBIN study. Diabetologia $\mathbf{5 1}$ 2060-2067. (doi:10.1007/s00125-008-1132-7)

Miller MA, McTernan PG, Harte AL, Silva NF, Strazzullo P, Alberti KG, Kumar S \& Cappuccio FP 2009 Ethnic and sex differences in circulating endotoxin levels: a novel marker of atherosclerotic and cardiovascular risk in a British multi-ethnic population. Atherosclerosis 203 494-502. (doi:10.1016/j.atherosclerosis.2008.06.018)

Mlinar B \& Marc J 2011 New insights into adipose tissue dysfunction in insulin resistance. Clinical Chemistry and Laboratory Medicine 49 1925-1935. (doi:10.1515/CCLM.2011.697)

Morino K, Neschen S, Bilz S, Sono S, Tsirigotis D, Reznick RM, Moore I, Nagai Y, Samuel V, Sebastian D et al. 2008 Muscle-specific IRS-1 $\mathrm{Ser} \rightarrow$ Ala transgenic mice are protected from fat-induced insulin resistance in skeletal muscle. Diabetes 57 2644-2651. (doi:10.2337/ db06-0454)

Morohoshi M, Fujisawa K, Uchimura I \& Numano F 1996 Glucosedependent interleukin 6 and tumor necrosis factor production by human peripheral blood monocytes in vitro. Diabetes 45 954-959. (doi:10.2337/diabetes.45.7.954)

Nagaev I \& Smith U 2001 Insulin resistance and type 2 diabetes are not related to resistin expression in human fat cells or skeletal muscle. Biochemical and Biophysical Research Communications 285 561-564. (doi:10.1006/bbrc.2001.5173)

Neuhouser ML, Schwarz Y, Wang C, Breymeyer K, Coronado G, Wang CY, Noar K, Song X \& Lampe JW 2012 A low-glycemic load diet reduces serum C-reactive protein and modestly increases adiponectin in overweight and obese adults. Journal of Nutrition 142 369-374. (doi:10.3945/jn.111.149807)

Nishimura S, Manabe I, Nagasaki M, Eto K, Yamashita H, Ohsugi M, Otsu M, Hara K, Ueki K, Sugiura S et al. 2009 CD8 + effector T cells contribute to macrophage recruitment and adipose tissue inflammation in obesity. Nature Medicine 15 914-920. (doi:10.1038/nm.1964)

O’Neill LA, Bryant CE \& Doyle SL 2009 Therapeutic targeting of Toll-like receptors for infectious and inflammatory diseases and cancer. Pharmacological Reviews 61 177-197. (doi:10.1124/pr.109.001073)

Ouchi N, Parker JL, Lugus JJ \& Walsh K 2011 Adipokines in inflammation and metabolic disease. Nature Reviews. Immunology 11 85-97. (doi:10.1038/nri2921)

Panee J 2012 Monocyte chemoattractant protein 1 (MCP-1) in obesity and diabetes. Cytokine 60 1-12. (doi:10.1016/j.cyto.2012.06.018)

Patel SD, Rajala MW, Rossetti L, Scherer PE \& Shapiro L 2004 Disulfidedependent multimeric assembly of resistin family hormones. Science 304 1154-1158. (doi:10.1126/science.1093466)

Pedersen TR, Wilhelmsen L, Faergeman O, Strandberg TE, Thorgeirsson G, Troedsson L, Kristianson J, Berg K, Cook TJ, Haghfelt T et al. 2000 Follow-up study of patients randomized in the Scandinavian simvastatin survival study (4S) of cholesterol lowering. American Journal of Cardiology 86 257-262. (doi:10.1016/S0002-9149(00)009103)

Peiris AN, Sothmann MS, Hoffmann RG, Hennes MI, Wilson CR, Gustafson AB \& Kissebah AH 1989 Adiposity, fat distribution, and cardiovascular risk. Annals of Internal Medicine 110 867-872.

Pelleymounter MA, Cullen MJ, Baker MB, Hecht R, Winters D, Boone T \& Collins F 1995 Effects of the obese gene product on body weight regulation in ob/ob mice. Science 269 540-543. (doi:10.1126/science. 7624776)

Pirola L, Johnston AM \& Van Obberghen E 2004 Modulation of insulin action. Diabetologia 47 170-184. (doi:10.1007/s00125-003-1313-3)

Pischon T, Boeing H, Hoffmann K, Bergmann M, Schulze MB, Overvad K, van der Schouw YT, Spencer E, Moons KG, Tjønneland A et al. 2008 General and abdominal adiposity and risk of death in Europe. New England Journal of Medicine 359 2105-2120. (doi:10.1056/ NEJMoa0801891)

Poggi M, Bastelica D, Gual P, Iglesias MA, Gremeaux T, Knauf C, Peiretti F, Verdier M, Juhan-Vague I, Tanti JF et al. 2007 C3H/HeJ mice carrying a Toll-like receptor 4 mutation are protected against the development of insulin resistance in white adipose tissue in response to a high-fat diet. Diabetologia 50 1267-1276. (doi:10.1007/s00125-007-0654-8)

Pradhan AD, Manson JE, Rifai N, Buring JE \& Ridker PM 2001 C-reactive protein, interleukin 6 , and risk of developing type 2 diabetes mellitus. Journal of the American Medical Association 286 327-334. (doi:10.1001/ jama.286.3.327)

ProspectiveStudiesCollaboration 2009 Body-mass index and cause-specific mortality in 900000 adults: collaborative analyses of 57 prospective studies. Lancet 373 1083-1096. (doi:10.1016/S0140-6736(09)60318-4)

Pussinen PJ, Havulinna AS, Lehto M, Sundvall J \& Salomaa V 2011 Endotoxemia is associated with an increased risk of incident diabetes. Diabetes Care 34 392-397. (doi:10.2337/dc10-1676)

Qi L, van Dam RM, Liu S, Franz M, Mantzoros C \& Hu FB 2006 Whole-grain, bran, and cereal fiber intakes and markers of systemic inflammation in diabetic women. Diabetes Care 29 207-211. (doi:10.2337/diacare.29.02. 06.dc05-1903)

Ramanjaneya M, Chen J, Brown JE, Tripathi G, Hallschmid M, Patel S, Kern W, Hillhouse EW, Lehnert H, Tan BK et al. 2010 Identification of nesfatin-1 in human and murine adipose tissue: a novel depotspecific adipokine with increased levels in obesity. Endocrinology 151 3169-3180. (doi:10.1210/en.2009-1358)

Randle PJ, Garland PB, Hales CN \& Newsholme EA 1963 The glucose fattyacid cycle. Its role in insulin sensitivity and the metabolic disturbances of diabetes mellitus. Lancet 1 785-789. (doi:10.1016/S0140-6736(63) 91500-9)

Rao RK, Seth A \& Sheth P 2004 Recent advances in alcoholic liver disease I. Role of intestinal permeability and endotoxemia in alcoholic liver disease. American Journal of Physiology. Gastrointestinal and Liver Physiology 286 G881-G884. (doi:10.1152/ajpgi.00006.2004)

Reiter LT, Potocki L, Chien S, Gribskov M \& Bier E 2001 A systematic analysis of human disease-associated gene sequences in Drosophila melanogaster. Genome Research 11 1114-1125. (doi:10.1101/ gr.169101)

Reyna SM, Ghosh S, Tantiwong P, Meka CS, Eagan P, Jenkinson CP, Cersosimo E, Defronzo RA, Coletta DK, Sriwijitkamol A et al. 2008 Elevated Toll-like receptor 4 expression and signaling in muscle from insulin-resistant subjects. Diabetes 57 2595-2602. (doi:10.2337/db080038)

Roman AA, Parlee SD \& Sinal CJ 2012 Chemerin: a potential endocrine link between obesity and type 2 diabetes. Endocrine 42 243-251. (doi:10.1007/s12020-012-9698-8)

Rotter V, Nagaev I \& Smith U 2003 Interleukin-6 (IL-6) induces insulin resistance in 3T3-L1 adipocytes and is, like IL-8 and tumor necrosis factor- $\alpha$, overexpressed in human fat cells from insulin-resistant subjects. Journal of Biological Chemistry 278 45777-45784. (doi:10.1074/ jbc.M301977200) 
Ruge T, Lockton JA, Renstrom F, Lystig T, Sukonina V, Svensson MK \& Eriksson JW 2009 Acute hyperinsulinemia raises plasma interleukin-6 in both nondiabetic and type 2 diabetes mellitus subjects, and this effect is inversely associated with body mass index. Metabolism $\mathbf{5 8}$ 860-866. (doi:10.1016/j.metabol.2009.02.010)

Sachot C, Poole S \& Luheshi GN 2004 Circulating leptin mediates lipopolysaccharide-induced anorexia and fever in rats. Journal of Physiology 561 263-272. (doi:10.1113/jphysiol.2004.074351)

Saiki A, Olsson M, Jernås M, Gummesson A, McTernan PG, Andersson J, Jacobson P, Sjöholm K, Olsson B, Yamamura S et al. 2009 Tenomodulin is highly expressed in adipose tissue, increased in obesity, and downregulated during diet-induced weight loss. Journal of Clinical Endocrinology and Metabolism 94 3987-3994. (doi:10.1210/jc.2009-0292)

Santos-Alvarez J, Goberna R \& Sánchez-Margalet V 1999 Human leptin stimulates proliferation and activation of human circulating monocytes. Cellular Immunology 194 6-11. (doi:10.1006/cimm.1999.1490)

Savage DB, Sewter CP, Klenk ES, Segal DG, Vidal-Puig A, Considine RV \& O'Rahilly S 2001 Resistin/Fizz3 expression in relation to obesity and peroxisome proliferator-activated receptor-gamma action in humans. Diabetes 50 2199-2202. (doi:10.2337/diabetes.50.10.2199)

van Schothorst EM, Bunschoten A, Schrauwen P, Mensink RP \& Keijer J 2009 Effects of a high-fat, low- versus high-glycemic index diet: retardation of insulin resistance involves adipose tissue modulation. FASEB Journal 23 1092-1101. (doi:10.1096/fj.08-117119)

Schwartz DR \& Lazar MA 2011 Human resistin: found in translation from mouse to man. Trends in Endocrinology and Metabolism 22 259-265. (doi:10.1016/j.tem.2011.03.005)

Selvin E, Marinopoulos S, Berkenblit G, Rami T, Brancati FL, Powe NR \& Golden SH 2004 Meta-analysis: glycosylated hemoglobin and cardiovascular disease in diabetes mellitus. Annals of Internal Medicine $\mathbf{1 4 1}$ $421-431$.

Senn JJ, Klover PJ, Nowak IA \& Mooney RA 2002 Interleukin-6 induces cellular insulin resistance in hepatocytes. Diabetes 51 3391-3399. (doi:10.2337/diabetes.51.12.3391)

Senn JJ, Klover PJ, Nowak IA, Zimmers TA, Koniaris LG, Furlanetto RW \& Mooney RA 2003 Suppressor of cytokine signaling-3 (SOCS-3), a potential mediator of interleukin-6-dependent insulin resistance in hepatocytes. Journal of Biological Chemistry 278 13740-13746. (doi:10.1074/jbc.M210689200)

Sever PS, Chang CL, Gupta AK, Whitehouse A, Poulter NR \& Investigators A 2011 The Anglo-Scandinavian Cardiac Outcomes Trial: 11-year mortality follow-up of the lipid-lowering arm in the U.K. European Heart Journal 32 2525-2532. (doi:10.1093/eurheartj/ehr333)

Shi H, Kokoeva MV, Inouye K, Tzameli I, Yin H \& Flier JS 2006 TLR4 links innate immunity and fatty acid-induced insulin resistance. Journal of Clinical Investigation 116 3015-3025. (doi:10.1172/JCI28898)

Shibata R, Ouchi N, Takahashi R, Terakura Y, Ohashi K, Ikeda N, Higuchi A, Terasaki H, Kihara S \& Murohara T 2012 Omentin as a novel biomarker of metabolic risk factors. Diabetology \& Metabolic Syndrome 437. (doi:10.1186/1758-5996-4-37)

Shimomura I, Funahashi T, Takahashi M, Maeda K, Kotani K, Nakamura T, Yamashita S, Miura M, Fukuda Y, Takemura K et al. 1996 Enhanced expression of PAI-1 in visceral fat: possible contributor to vascular disease in obesity. Nature Medicine 2 800-803. (doi:10.1038/ nm0796-800)

Shoelson SE, Lee J \& Yuan M 2003 Inflammation and the IKK $\beta /$ I kappa B/NF-kappa B axis in obesity- and diet-induced insulin resistance. International Journal of Obesity and Related Metabolic Disorders 27(Suppl 3) S49-S52. (doi:10.1038/sj.ijo.0802501)

Shoelson SE, Lee J \& Goldfine AB 2006 Inflammation and insulin resistance. Journal of Clinical Investigation 116 1793-1801. (doi:10.1172/ JCI29069)

Smith SR, Lovejoy JC, Greenway F, Ryan D, deJonge L, de la Bretonne J, Volafova J \& Bray GA 2001 Contributions of total body fat, abdominal subcutaneous adipose tissue compartments, and visceral adipose tissue to the metabolic complications of obesity. Metabolism $\mathbf{5 0} 425-435$ (doi:10.1053/meta.2001.21693)

Soop M, Duxbury H, Agwunobi AO, Gibson JM, Hopkins SJ, Childs C, Cooper RG, Maycock P, Little RA \& Carlson GL 2002 Euglycemic hyperinsulinemia augments the cytokine and endocrine responses to endotoxin in humans. American Journal of Physiology. Endocrinology and Metabolism 282 E1276-E1285. (doi:10.1152/ajpendo.00535.2001)

Soriguer F, Garrido-Sanchez L, Garcia-Serrano S, Garcia-Almeida JM, Garcia-Arnes J, Tinahones FJ \& Garcia-Fuentes E 2009 Apelin levels are increased in morbidly obese subjects with type 2 diabetes mellitus. Obesity Surgery 19 1574-1580. (doi:10.1007/s11695-009-9955-y)

de Souza Batista CM, Yang R-Z, Lee M-J, Glynn NM, Yu D-Z, Pray J, Ndubuizu K, Patil S, Schwartz A, Kligman M et al. 2007 Omentin plasma levels and gene expression are decreased in obesity. Diabetes 56 1655-1661. (doi:10.2337/db06-1506)

Sporn MB, Roberts AB, Wakefield LM \& de Crombrugghe B 1987 Some recent advances in the chemistry and biology of transforming growth factor- $\beta$. Journal of Cell Biology 105 1039-1045. (doi:10.1083/ jcb.105.3.1039)

Spranger J, Kroke A, Möhlig M, Bergmann MM, Ristow M, Boeing H \& Pfeiffer AF 2003 Adiponectin and protection against type 2 diabetes mellitus. Lancet 361 226-228. (doi:10.1016/S0140-6736(03)12255-6)

Stanley TL, Zanni MV, Johnsen S, Rasheed S, Makimura H, Lee H, Khor VK, Ahima RS \& Grinspoon SK 2011 TNF- $\alpha$ antagonism with etanercept decreases glucose and increases the proportion of high molecular weight adiponectin in obese subjects with features of the metabolic syndrome. Journal of Clinical Endocrinology and Metabolism 96 E146-E150. (doi:10.1210/jc.2010-1170)

Starkie R, Ostrowski SR, Jauffred S, Febbraio M \& Pedersen BK 2003 Exercise and IL- 6 infusion inhibit endotoxin-induced TNF- $\alpha$ production in humans. FASEB Journal 17 884-886. (doi:10.1096/fj.02-0670fje)

Steppan CM, Bailey ST, Bhat S, Brown EJ, Banerjee RR, Wright CM, Patel HR, Ahima RS \& Lazar MA 2001 The hormone resistin links obesity to diabetes. Nature 409 307-312. (doi:10.1038/35053000)

Straczkowski M, Dzienis-Straczkowska S, Stêpieñ A, Kowalska I, Szelachowska M \& Kinalska I 2002 Plasma interleukin-8 concentrations are increased in obese subjects and related to fat mass and tumor necrosis factor- $\alpha$ system. Journal of Clinical Endocrinology and Metabolism 87 4602-4606. (doi:10.1210/jc.2002-020135)

Stratton IM, Adler AI, Neil HA, Matthews DR, Manley SE, Cull CA, Hadden D, Turner RC \& Holman RR 2000 Association of glycaemia with macrovascular and microvascular complications of type 2 diabetes (UKPDS 35): prospective observational study. BMJ 321 405-412. (doi:10.1136/bmj.321.7258.405)

Szabo G, Velayudham A, Romics L \& Mandrekar P 2005 Modulation of nonalcoholic steatohepatitis by pattern recognition receptors in mice: the role of Toll-like receptors 2 and 4. Alcoholism, Clinical and Experimental Research 29(11 Suppl) 140S-145S. (doi:10.1097/01.alc.0000189287. 83544.33)

Tanji T \& Ip YT 2005 Regulators of the Toll and Imd pathways in the Drosophila innate immune response. Trends in Immunology 26 193-198. (doi:10.1016/j.it.2005.02.006)

Tilg H \& Moschen AR 2008 Inflammatory mechanisms in the regulation of insulin resistance. Molecular Medicine 14 222-231. (doi:10.2119/ 2007-00119.Tilg)

Tsukumo DM, Carvalho-Filho MA, Carvalheira JB, Prada PO, Hirabara SM, Schenka AA, Araújo EP, Vassallo J, Curi R, Velloso LA et al. 2007 Loss-of-function mutation in Toll-like receptor 4 prevents diet-induced obesity and insulin resistance. Diabetes 56 1986-1998. (doi:10.2337/db06-1595)

Tzanavari T, Giannogonas P \& Karalis KP 2010 TNF- $\alpha$ and obesity. Current Directions in Autoimmunity 11 145-156. (doi:10.1159/000289203)

Wajchenberg BL 2000 Subcutaneous and visceral adipose tissue: their relation to the metabolic syndrome. Endocrine Reviews 21 697-738. (doi:10.1210/er.21.6.697) 
Weigert J, Neumeier M, Wanninger J, Filarsky M, Bauer S, Wiest R, Farkas S, Scherer MN, Schäffler A, Aslanidis C et al. 2010 Systemic chemerin is related to inflammation rather than obesity in type 2 diabetes. Clinical Endocrinology 72 342-348. (doi:10.1111/j.1365-2265.2009.03664.x)

Weisberg SP, McCann D, Desai M, Rosenbaum M, Leibel RL \& Ferrante AW Jr 2003 Obesity is associated with macrophage accumulation in adipose tissue. Journal of Clinical Investigation 112 1796-1808. (doi:10.1172/ JCI19246)

Whitehead JP, Richards AA, Hickman IJ, Macdonald GA \& Prins JB 2006 Adiponectin - a key adipokine in the metabolic syndrome. Diabetes, Obesity \& Metabolism 8264-280. (doi:10.1111/j.1463-1326.2005.00510.x)

Wu J, Bostrom P, Sparks LM, Ye L, Choi JH, Giang AH, Khandekar M, Virtanen KA, Nuutila P, Schaart G et al. 2012a Beige adipocytes are a distinct type of thermogenic fat cell in mouse and human. Cell 150 366-376. (doi:10.1016/j.cell.2012.05.016)

Wu LH, Huang CC, Adhikarakunnathu S, San Mateo LR, Duffy KE, Rafferty P, Bugelski P, Raymond H, Deutsch H, Picha K et al. 2012b Loss of Toll-like receptor 3 function improves glucose tolerance and reduces liver steatosis in obese mice. Metabolism 61 1633-1645. (doi:10.1016/j.metabol.2012.04.015)

Xiao E, Xia-Zhang L, Vulliémoz NR, Ferin M \& Wardlaw SL 2003 Leptin modulates inflammatory cytokine and neuroendocrine responses to endotoxin in the primate. Endocrinology 144 4350-4353. (doi:10.1210/en.2003-0532)

Yang Q 2005 Serum retinol binding protein 4 contributes to insulin resistance in obesity and type 2 diabetes. Nature 436 356-362. (doi:10.1038/nature03711)

Youssef-Elabd EM, McGee KC, Tripathi G, Aldaghri N, Abdalla MS, Sharada HM, Ashour E, Amin AI, Ceriello A, O'Hare JP et al. 2012 Acute and chronic saturated fatty acid treatment as a key instigator of the TLR-mediated inflammatory response in human adipose tissue, in vitro. Journal of Nutritional Biochemistry 23 39-50. (doi:10. 1016/j.jnutbio.2010.11.003)

Yu S, Zhang Y, Li MZ, Xu H, Wang Q, Song J, Lin P, Zhang L, Liu Q, Huang QX et al. 2012 Chemerin and apelin are positively correlated with inflammation in obese type 2 diabetic patients. Chinese Medical Journal 125 3440-3444.

Yuan M, Konstantopoulos N, Lee J, Hansen L, Li ZW, Karin M \& Shoelson SE 2001 Reversal of obesity- and diet-induced insulin resistance with salicylates or targeted disruption of Ikk $\beta$. Science $\mathbf{2 9 3}$ 1673-1677. (doi:10.1126/science.1061620)

Yue P, Jin H, Xu S, Aillaud M, Deng AC, Azuma J, Kundu RK, Reaven GM, Quertermous T \& Tsao PS 2011 Apelin decreases lipolysis via G(q), G(i), and AMPK-dependent mechanisms. Endocrinology 152 59-68. (doi:10.1210/en.2010-0576)

Zhang Y, Proenca R, Maffei M, Barone M, Leopold L \& Friedman JM 1994 Positional cloning of the mouse obese gene and its human homologue. Nature 372 425-432. (doi:10.1038/372425a0)

Zhang Y, Shen C, Li X, Ren G, Fan X, Ren F, Zhang N, Sun J \& Yang J 2009 Low plasma apelin in newly diagnosed type 2 diabetes in Chinese people. Diabetes Care 32 e150. (doi:10.2337/dc09-1146)

Zhong X, Li X, Liu F, Tan H \& Shang D 2012 Omentin inhibits TNF- $\alpha$-induced expression of adhesion molecules in endothelial cells via ERK/NF-kappaB pathway. Biochemical and Biophysical Research Communications 425 401-406. (doi:10.1016/j.bbrc. 2012.07.110)

Ziccardi P, Nappo F, Giugliano G, Esposito K, Marfella R, Cioffi M, D'Andrea F, Molinari AM \& Giugliano D 2002 Reduction of inflammatory cytokine concentrations and improvement of endothelial functions in obese women after weight loss over one year. Circulation 105 804-809. (doi:10.1161/hc0702.104279)

Received in final form 31 October 2012

Accepted 16 November 2012

Accepted Preprint published online 16 November 2012
C 2013 Society for Endocrinology Printed in Great Britain
Published by Bioscientifica Ltd. 